\title{
Making Armenian Politically Exposed Persons' Money Public: A Data-Driven Journalism Project That Aims to Create a Database of Armenian MPs' Assets
}

Ani Hovhannisyan

West Virginia University, ah0039@mix.wvu.edu

Follow this and additional works at: https://researchrepository.wvu.edu/etd

Part of the Communication Technology and New Media Commons, Journalism Studies Commons, Social Influence and Political Communication Commons, and the Social Media Commons

\section{Recommended Citation}

Hovhannisyan, Ani, "Making Armenian Politically Exposed Persons' Money Public: A Data-Driven Journalism Project That Aims to Create a Database of Armenian MPs' Assets" (2019). Graduate Theses, Dissertations, and Problem Reports. 7660.

https://researchrepository.wvu.edu/etd/7660

This Problem/Project Report is protected by copyright and/or related rights. It has been brought to you by the The Research Repository @WVU with permission from the rights-holder(s). You are free to use this Problem/Project Report in any way that is permitted by the copyright and related rights legislation that applies to your use. For other uses you must obtain permission from the rights-holder(s) directly, unless additional rights are indicated by a Creative Commons license in the record and/ or on the work itself. This Problem/Project Report has been accepted for inclusion in WVU Graduate Theses, Dissertations, and Problem Reports collection by an authorized administrator of The Research Repository @ WVU. For more information, please contact researchrepository@mail.wvu.edu. 
Making Armenian Politically Exposed Persons' Money Public: A Data-Driven Journalism Project That Aims to Create a Database of Armenian MPs' Assets

Ani Hovhannisyan 
Making Armenian Politically Exposed Persons' Money Public

A Data-Driven Journalism Project That Aims to Create a Database of Armenian MPs' Assets

Ani Hovhannisyan

Problem report submitted

to the Reed College of Media

at West Virginia University

in partial fulfillment of the requirements for the

degree of

Master of Science in Journalism

Steve Urbanski, Ph.D., Chair

Bob Britten, Ph.D

Jeffrey Moser, MFA

Stephen Kurkjian

Department of Journalism

Morgantown, West Virginia

2019

Keywords: data journalism, database, project, data-driven journalism, money, asset, income, Armenia, PEP

Copyright 2018: Ani Hovhannisyan 


\begin{abstract}
Making Armanian Politically Exposed Persons' Money Public

A Data-Driven Journalism Project That Aims to Create a Database of Armenian MPs' Assets
\end{abstract}

Ani Hovhannisyan

This data-driven journalism project tackles an age-old problem that seems common in virtually every government around the world: governmental officials hiding assets. By applying the theory of social responsibility, this paper uses data-journalism methods to trace the full financial assets of Armenian members of parliament and eventually making those asset and income declarations available via an interactive website to the Armenian public as well as other journalists throughout the country and region. 


\section{Contents}

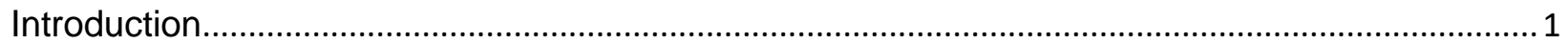

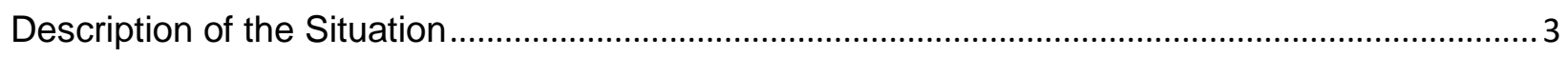

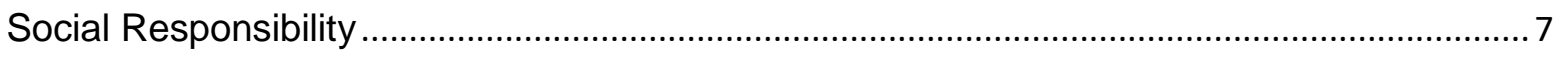

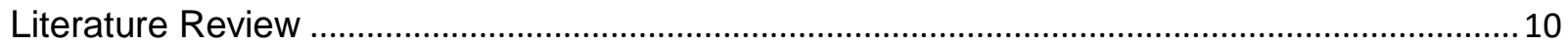

A tool to make Asset and Income Declaration data open and functional ......................................13

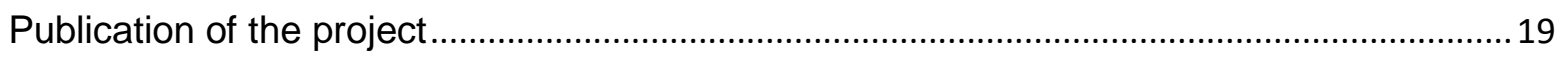

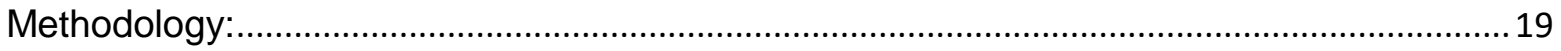

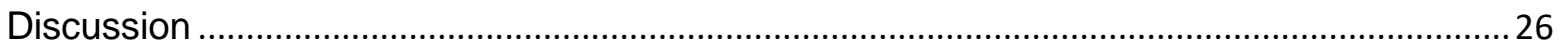

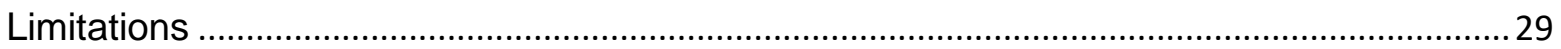

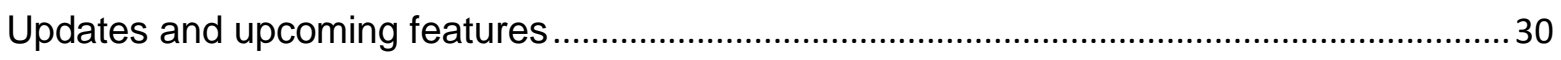

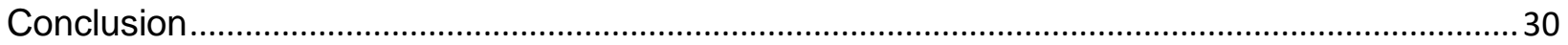

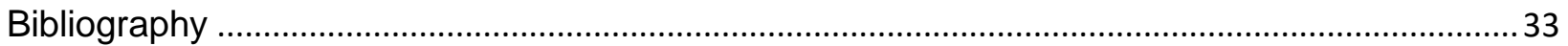


Introduction

Asset and Income Disclosure of the Politically Exposed Persons (PEPs) is one of the ever-growing set of practices in developing countries required by the Financial Action Task Force (FATF) ${ }^{1}$ recommendations. Policy developers define PEPs as individuals who are, or have been, entrusted with prominent public functions ${ }^{2}$ (Greenberg \& Gray, 2010). This definition, however, is very broad and often causes confusion and frustration in the implementation phase for the local jurisdictions of member countries and for standard setters. Greenberg and Gray (2010) find that the lack of clear definition serves as an excuse for some country jurisdictions to not require comprehensive asset disclosure reports from all public officials (p. 25-26). Besides that, the term PEP in some counties implies only state officials and their family members, others also include their business partners, company ties and close associates.

The most widespread standard that has been implemented in 176 World Bank client countries during last decade is the Asset Disclosure Standard. It requires civil servants of executive, legislative and judicial authorities, as well as their family members to declare their assets and income annually. An asset declaration consists of a balance sheet that covers movable and immovable property, liabilities, debts and mortgages, and all sources of revenue that the PEP obtains (Transparency International, 2013). Ideally,

\footnotetext{
${ }^{1}$ FATF is an inter-governmental body whose aim is to protect the global financial system through policies against money laundering, financing of terrorism, a proliferation of weapons of mass destruction. The nature of FATF recommendations is the prevention of global money laundering that may cause harmful consequences (FATF, 2012).

2 This paper takes the approach of Greenberg and Gray (2010, p. 25) using the same definition as the FATF and United Nations Convention against Corruption agreed about.
} 
it also should include all the received gifts, potential conflicts of interest and the declarer's membership in non-governmental organizations.

There are two types of Asset Disclosure: financial and business. The first includes information about PEP's real estate, vehicles, owned artworks, jewelry, investments, liabilities, and shares. Business disclosure applies to bank accounts, business interests and affiliated companies (Rossi, Pop, Clementucci, \& Sawaqed, 2012)

The level of the declarations' comprehensiveness varies from country to country: some require the official to open financial sources to the public fully, others hide key information thwarting the demand of keeping civil servants accountable. The World Bank Group assessed the publicity of the income and asset disclosure process in 176 client countries, of which 78 percent have financial disclosure systems but only 43 percent give the public access to those disclosures (World Bank Press Release, 2012). It means that almost half of the World Bank's client countries keep their PEPs' property hidden from citizens.

Armenia is one of the World Bank's client countries that implemented Asset and Income Declaration system at the government level. Moreover, the country has recognized the FATF recommendations as a universal standard against moneylaundering. It is a post-Soviet country in transition where a revolution took place in April 2018.

In 2012 The Commission on Ethics of High-Ranking Officials was established in Armenia by the Law on Public Service. The primary responsibilities of the commission 
are to maintain the income and property declaration registry and to discover conflicts of interests and violations of ethics rules by high-ranking officials.

The asset disclosure system in Armenia is a website of thousands of disorganized, unsearchable files where finding information, combining and drawing comparisons can be challenging for journalists. Additionally, most Armenian citizens are not aware of the declarations' website because of the lack of state promotion.

This project will analyze how international anti-corruption and anti-money laundering standards have been implemented in Armenia. Additionally, it will provide a tool for helping journalists to utilize Asset Disclosure Standard for public benefit and accountable governance.

\section{Description of the Situation}

In 2015, the European Union and the United States Agency for International Development provided funds to the government of Armenia for the creation of the AntiCorruption Council. Ideally, the council was designed to include members from opposition parties, civil society, non-governmental organizations, and representatives from the mass media but none of the representatives from the opposition or non-governmental sector joined because of distrust they had towards the council's work. Eventually, Armenia's prime minister was appointed as the president and several ministers have become members of the Anti-Corruption Council of Armenia (Decision of the Prime Minister N847A, 2015).

Paradoxically, the public officials who were accused of corruption launched the council to fight against corruption. For example, the ex-president of the council and ex- 
Armenia prime minister Hovik Abrahamyan has built a multi-million-dollar business "empire" during his tenure (Balasanyan, 2014). Also, right after becoming the president of Anti-Corruption Council, Abrahamyan flew to Paris on an official visit, and the government paid approximately $\$ 66,000$ for his round-trip ticket while the most expensive ticket (at the time) for that destination cost \$3,340 (Grigoryan, 2015). Similarly, in 2015 Armenian taxpayers paid for other flights that Abrahamian took: Prague $(\$ 43,000)$, Astana $(\$ 34,000)$ and Moscow $(\$ 54,000)$, all while the average monthly wage in Armenia was \$358 (Armstat, 2015).

Furthermore, instead of positive results, the operation of Commission on Ethics of High-Ranking Officials and Anti-Corruption Council corresponded with a negative shift in the corruption perception levels in the country. In 2014, Armenia ranked 94 out of 175 countries on corruption perception index (Corruption Perception Index, 2014). In 2016, a year after the establishment of the Anti-Corruption Council, the ranking dropped to 113 out of 176 (Corruption Perception Index, 2016).

Armenia's president Serj Sarkissian has governed the country for 10 years. In 2015, his ruling party voted to change the constitution converting Armenia from a presidential government to one ruled by a parliament. The move was risky because Sarkissian, according to the new constitution, needed to run for the prime minister after completing his presidential term. Because the majority of the parliament was from Sarkissian's party, he was elected as Armenia's prime minister in March 2018.

This move provoked an enormous amount of public discontent, and massive protests began in Yerevan, Armenia's capital city of one and a half million people, 
demanding Sarkissian's resignation. The demonstrations were headed by Nikol Pashinyan - an opposition member of parliament. On April $23^{\text {rd }}$, after weeks of demonstrations, the newly elected Sarkissian resigned, and the parliament eventually elected Pashinyan as the new prime minister of Armenia. The demonstrations were largely peaceful, so peaceful that the international media and Pashinyan referred to the event as a "Velvet Revolution."

In the months following the revolution, the political climate has changed in Armenia. Unlike the public distrust and disappointment that largely shrouded the previous government, Armenians expect the new government to be more transparent, accountable and honest.

Nevertheless, the policy transformation takes longer than the change of public opinion. Asset and Income declarations filed by the state officials and their family members remain partially obscured with key facts hidden from the public view.

For example, MP Samvel Aleksanyan assures that he is not engaged in any business activity as the Constitution of Armenia prohibits Parliament Members from being personally engaged in an entrepreneurial activity (Amendments to the Constitution of the Republic of Armenia, 2015). The annual salary of Aleksanyan is 2.2 million Armenian Dram ( $\$ 4,605$ U.S.), but his financial capacity is 335.19 million Armenian Dram (converted 70,429 USD) and USD 8.1 million (Samvel Aleksanyan's Declaration, 2017). Besides, he declared two real estate buildings, two industrial buildings and seven lots. A question arises: How can a Parliament member hold that much money and property with the 
declared amount of salary? Aleksanyan would need to work as an MP for 1,774 years without spending a dollar from his salary to be able to accrue that much financial capital.

One of the main functions of The Commission on Ethics of High-Ranking Officials is the detection of conflicts of interest in the cases foreseen in the Law on Public Service. However, the institution has never reported on Aleksanyan's declarations. Unfortunately, his case is not an exception, and most of the rich MPs' declarations are similar (Declarations Registry of Armenia, 2017).

Asset Disclosure itself does not reveal the corruption; however, it serves as a compass for investigative journalists to find hidden assets and undeclared wealth. The implementation of Asset Disclosure Standard in Armenia led to numerous journalistic investigations and political scandals due to the available or hidden information about PEPs' assets. For example, the current president Armen Sargsyan who was Armenia's former Ambassador to Great Britain did not declare any of his business companies and commercial holdings registered in Russia, Europe, the United States, various CIS countries, and in offshore zones (Baghdasaryan \& Aghalaryan, Hetq, 2018).

Journalists were able to reveal Sargsyan's hidden businesses by digging into databases of company registries and comparing their findings with the president's asset and income declaration. In other words, it was an investigation driven by a huge amount of data on business entities. Journalism driven by data is called data-driven journalism, and it suggests numerous tools to reveal corruption. 
Social Responsibility

This research and data-driven project fits the concept of social responsibility theory aiming to help the public to fight against corruption. The reason of accounting for the money of the politically exposed persons is not writing scandals with big headlines but keeping them accountable to the public because the goal of a data journalist is not only telling visually engaging stories but also helping citizens and policymakers to make better decisions for the future (Constantaras, 2016).

Social responsibility theory was given importance in American journalism because of the ethical problems occurred during the period when libertarian agenda of the press was actual (Uzuegbunam, 2015). Initially, the base of the libertarian theory was diversity, plurality of media outlets and freedom from the government elites. However, it led the media outlets in the United States to focus more on ownership which created a solid link between big corporations and media organizations resulting in the press becoming part of the power elites (Akhavan-Majid, 1991).

The Hutchins Commission, a 1947 panel of non-journalists, urged that the freedom of press was in danger under libertarian agenda and posed social responsibility theory of the press. The Commission was officially called the Commission on Freedom of the Press chaired by Robert Hutchins, the president of the University of Chicago at that time. In the report called "A Free and Responsible Press", members of the Commission criticized the growing tendency of media ownership as it directly influenced the content of newspapers. News organizations were either voluntarily or forcibly were more responsible in front of big corporations than society (Blanchard, 1977). 
The Commission has clearly stated that the press is responsible for establishing accountability and educating the public because "...the conscience of the citizen is the source of the continued vitality of the state" (Hutchins \& Chafee, 1947, p. 9). Hutchins Commission's responsibility concept served as a guide to create policy in journalism practice (Mclntyre, 1987).

Currently, the vast amount of information, uncovered big data and leaked financial documents give contemporary journalists more possibilities to reveal corruption and establish accountability. In the $21^{\text {st }}$ century, there have been dozens of data-fueled publications by media outlets that have resulted in civil servants resigning. "The Panama Papers," The Guardian's "MPs' Expenses" are two examples of such change-making data-driven investigations.

The Panama Papers investigation revealed that 12 national leaders and 131 other politicians, their families and close circles from around the world were using offshore tax havens to hide their wealth (Garside, Watt, \& Pegg, 2016). This investigation led to the resignation of Iceland's prime minister Sigmundur Gunnlaugsso, Ukrainian prime minister Arseny Yatsenyuk, Pakistan's prime minister Nawaz Sharif, Spain's industry, energy and tourism minister José Manuel Soria and Chile's head of Transparency International Gonzalo Delaveau as their names appeared in a leak of 11.5 million documents from Panama-based law firm Mossack Fonseca known for arranging offshore companies (Kroll, 2016).

The Panama Papers was a massive data journalism project in collaboration with around 400 journalists from more than 100 media organizations in over 80 countries. They 
researched 2.6 terabytes of leaked company records to uncover government officials' corrupted deals in the Panamanian offshore zone (Obermaier, Obermayer, Wormer, \& Jaschensky, 2017). The investigation took about a year when the computer scientists organized data (emails, PDF and TIFF files) in one searchable dashboard and journalists dug through it to find files connected to their country's high-ranking officials (Cabra \& Kissane, 2016).

Another example of data journalism that led to corruption disclosure and public officials' disqualification was The Guardian's project called "MPs' Expenses." In 2009 the House of Commons of the United Kingdom had released about 700,000 individual documents containing receipts, mortgages, home and furniture purchases of all 646 members of the Parliament (Rogers, The Guardian, 2009). Documents were in PDF format that required manual analysis, so The Guardian asked readers to help. Using a special crowdsourcing application, they could check MP's expenses, highlight the most questionable ones, and tell the newspaper why that receipts need more investigation.

The Guardian's data journalists have disclosed cases of legal abuse by the members of Parliament, such as declaring second homes as their main residence, renting out homes, avoiding tax, overspending at the end of the financial year. This data-driven investigation resulted in dozens of resignations, retirement announcements, public apologies and repayment of expenses by the members of parliament. Six MPs were prosecuted and sentenced to terms of imprisonment (Hattenstone, 2012).

The MPs' Expenses project shows the significant role of data journalism in establishing transparent governance and revealing corruption (Gray, Bounegru, \& 
Chambers, 2012). Furthermore, public access to data strengthens the participatory culture (Jenkins, 2006) where citizens take part in a corruption uncovering process by their contribution in data analysis phase.

\section{Literature Review}

The role of data-driven journalism is to pull stories out of raw data like a sculptor creating art by carefully chipping away at a marble slab. Data journalists are guided by the following common rules while generating stories from data: testing hypotheses, showing trends and contrasts, revealing startling outliers and finding invisible connections (Constantaras, 2016).

The link between data and journalism was firstly proposed by Philip Meyer in 1969. According to him, data-driven journalism uses the same methods for newsgathering as social and behavioral sciences for scientific research. Therefore, Meyer termed it "precision journalism" (Meyer, 1991).

Finding stories in data is the most recent definition of data journalism (Gray, Bounegru, \& Chambers, 2012). However, it is not as easy as it sounds: some specific knowledge and skills are required to analyze data and make accurate conclusions.

Several different fields are involved in the process of data-driven story production: statistical analysis, computer science, visualization, web design and reporting (Coddington, 2015). That is why data journalism is considered a highly collaborative discipline (Hewett, 2017). Leading media organizations like The New York Times, The Guardian, ProPublica and Los Angeles Times have formed and are expanding their data journalism teams consisting of computer scientists, statisticians, journalists, and 
designers. Their practice spreads internationally as more and more news organizations from Latin America, Eastern Europe, and Post Soviet countries integrate programmers into their newsrooms.

Global Investigative Journalism Network observed the formulation process of several data journalism teams in Latin America, based on which it suggests tips for building a successful data team (López, GIJN, 2017). It worth referring to some of them in detail.

1. It is not necessary to have a big team to do big projects. The most important is to have the right people on the team. Ojo Público digital media site that is based in Peru won Data Journalism Award in 2017 with its tiny team.

2. Data journalism teams need to have two types of developers: back-end and front-end. Back-end programmers are responsible for constructing, managing and securing the database. Front-end developers are in charge of the visual interface and interactivity.

3. The new team must be formulated with a new mentality. Data journalists should switch their focus from questioning one case to questioning the patterns and trends of thousands of cases.

4. Transparency is an integral part of data-driven journalism. Data journalists not only require the government to be transparent but also provide a transparent method of their own findings. Every published data journalism project has the 
method and data enclosed, so readers can download it and double check the calculations (López, Global Investigative Journalism Network, 2017).

There are different data sources: government websites, international organizations, leaked or private sources etc. However, data journalism veterans consider that the basis of data journalism is publicly available and open data (Rogers, The Guardian, 2012). The openness of data is one of the essential conditions for the development of data journalism.

The term "openness" in relation to data, according to the Open Definition website, means anyone can freely access, use, modify and share the data for any purpose (Constantaras, 2016). Schellong and Stepanets (2011) demonstrate eight principles that serve as an indicator to measure if data is open or not:

1. Completeness: all public data are made available. The data are public if it is not subject to valid privacy, security or privilege limitations.

2. Primacy: data are collected not in aggregate or modified forms.

3. Timeliness: data are made available as quickly as possible to preserve the value of the data.

4. Accessibility: data are available to the broadest range of users for the widest range of purposes.

5. Machine readability: data are reasonably structured to allow automated processing. 
6. Non-discriminatory: data are available to anyone, with no requirement of registration.

7. Non-proprietary: data are available in a format over which no entity has exclusive control.

8. License-free: Data are not subject to any copyright, patent, trademark or trade secret regulation. Reasonable privacy, security and privilege restrictions may be allowed (Stepanets, 2011, p. 11).

The absence of any of the principles mentioned above makes data not open or partially open. For example, even though the asset and income declarations of Armenian MPs are publicly available, they cannot be considered open because they are not machine readable (are in PDF format) and complete (key aspects such as the amount and the location of shares are hidden).

In a situation where both international standards and state reforms do not guarantee public accountability, the role of data-driven journalism becomes more urgent. In this case, data is the information contained in Asset declarations and journalism is the way of making that data easily accessible and attractive for the wide public.

A tool to make Asset and Income Declaration data open and functional

The objective of this project goes beyond pointing out problems to presenting solutions. An organized, searchable, functional and interactive database of PEPs' asset and income declaration is a useful tool to increase the public interest towards accountable governance in Armenia. Moreover, the database allows taxpayers to easily access and check the assets declared by the PEPs whom they voted for. 
Together with this research, the researcher has created a database containing around 6,000 Asset and Income declarations of almost 2500 Armenian PEPs. Each PEP has a profile with photo, biography, contact information and asset declarations starting from 2011. Besides that, a small connection map shows PEPs' affiliated people - family members, relatives, business associates, friends etc. All the information in the database was taken from credible publicly available sources such as voters registry, financial reports, and government websites.

Below is the example of one Member of Parliament's database profile (url: https://data.hetq.am/en/profile/98): 


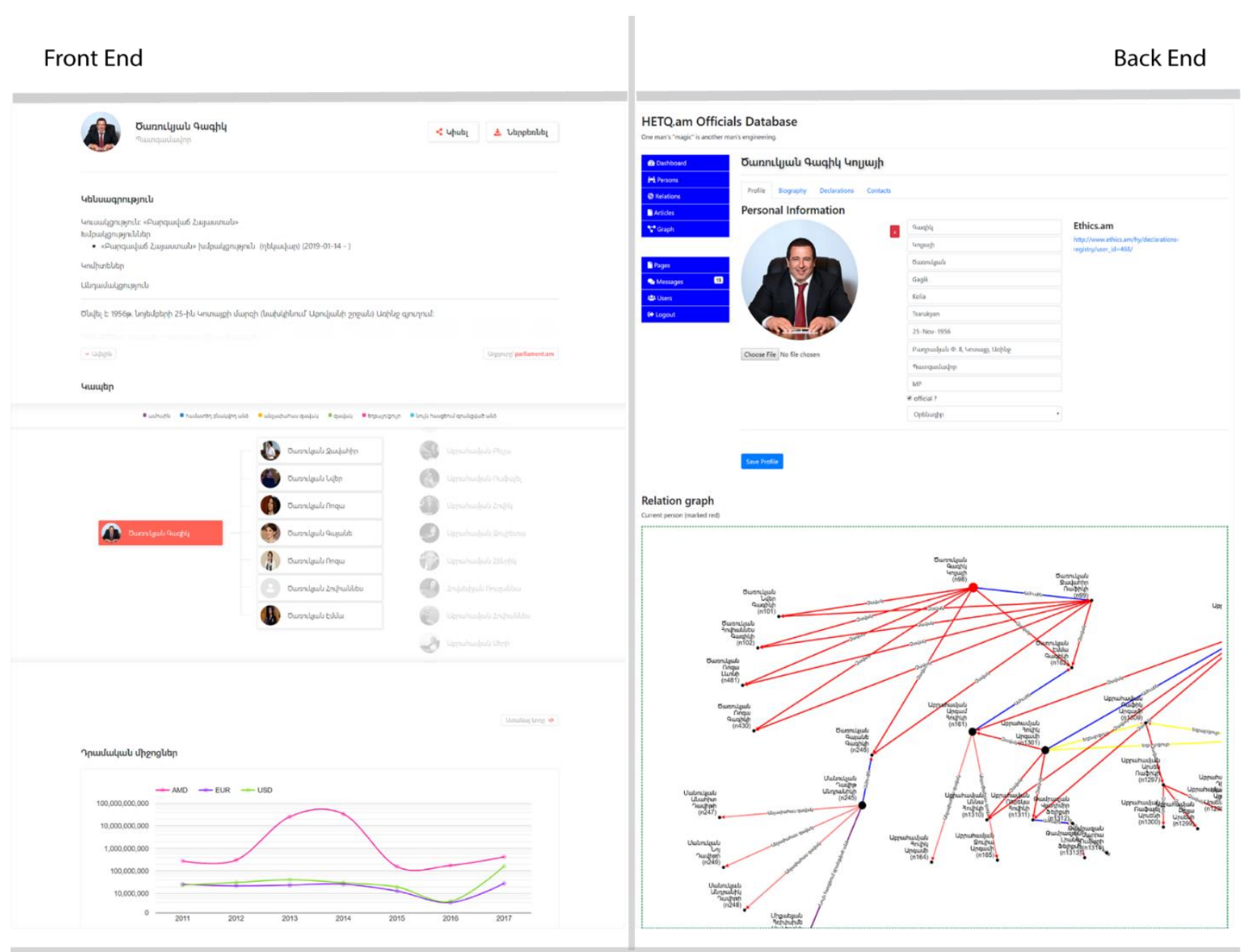

Figure 1 Armenian MP Gagik Tsarukyan's profile on the database tool created by the researcher and the team.

On the left side is the front-end ${ }^{3}$ view of the PEP's profile where users can read his biography, check out his affiliated people via the interactive tree map and see the amount of money he declared. On the right side is the back-end ${ }^{4}$ view of the same profile where researcher inserts, edits and organizes data. A unique relation graph was made manually for every PEP. It shows PEPs' close associates and family members, also it draws the path connecting two or more PEPs.

${ }^{3}$ Graphical interface available for users.

${ }^{4}$ Data access and structure layer or dashboard where only data editors and developers have an access in order to edit or insert data. 
Usually, data-driven projects are implemented by a team consisting of a journalist, a programmer, a designer and a data scientist (depending on a project characteristics) because it is nearly impossible for a single journalist to organize, analyze thousands of documents, and make them visually functional without the assistance of programmers. For this particular database, the team consisted of a journalist/researcher, a programmer, and a web designer.

To hire a programmer and a web designer, the journalist/researcher applied for funding from different international organizations operating in Armenia. In August 2018, Eurasia Partnership Foundation Armenia ${ }^{5}$ allocated funds $(14,000,000$ AMD $\approx 30,000$ USD) to create the Asset and Income Database of Armenian Members of Parliament. After receiving the grant the following actions were taken to implement the project.

August 2018, team formation: An open call was announced for programmer and web designer positions. Two people were selected out of 31 applications. Server and hosting services were bought to host the database.

September 2018, constructing the back-end database, scrapping and organizing data: The journalist/researcher and programmer developed effective solutions for database construction. The core point was to provide a highly functional basis for inputting a large amount of data. After the completion of the database construction plan, the programmer

\footnotetext{
${ }^{5}$ Eurasia Partnership Foundation's mission, according to their website, is to empower people to effect change for social justice and economic prosperity through hands-on programs, helping them to improve their communities and their own lives (EPF, n.d.).
} 
developed several scripts ${ }^{6}$ that automatically scraped data from the website of The Commission on Ethics of High-Ranking Officials and input in the database.

Asset and Income declarations in Armenia are published in non-machine-readable format. Specifically, those are document files with disordered tables on it. Scripts helped to convert the data of asset documents into machine-readable formats ${ }^{7}$ without any human error. This format allows to calculate the wealth, analyze connections and determine story angles out of raw data.

\begin{tabular}{|c|c|c|c|c|c|c|c|c|}
\hline & \multicolumn{8}{|c|}{ 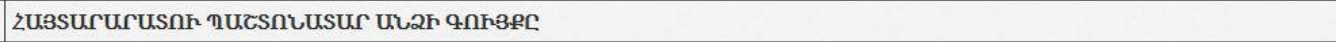 } \\
\hline & \multicolumn{8}{|c|}{ 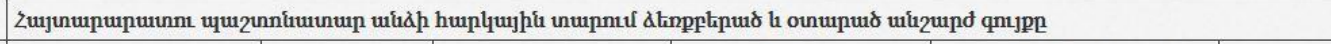 } \\
\hline \multirow{2}{*}{$\begin{array}{l}\mathrm{NN} \\
\mathrm{p} / \mathrm{l}\end{array}$} & \multirow{2}{*}{ Stuuule } & \multirow{2}{*}{$\begin{array}{l}\text { Quniulthinı } \\
\text { \uuph huugtí }\end{array}$} & \multirow{2}{*}{$\begin{array}{l}\text { Unlqu t huplquijhis } \\
\text { nuplu ulqqphi }\end{array}$} & \multicolumn{2}{|c|}{$\begin{array}{l}\text { 2tnp t phnulth } \\
\text { huplquujht unupnud }\end{array}$} & \multicolumn{2}{|c|}{$\begin{array}{l}\text { Onupulth t huplquujhi } \\
\text { numpnu }\end{array}$} & \multirow{2}{*}{$\begin{array}{l}\text { Unluut } \\
\text { huplquupht } \\
\text { unuplu } \\
\text { ythpenud }\end{array}$} \\
\hline & & & & $\begin{array}{l}\text { qhing } \\
\text { (undthp) }\end{array}$ & undnujp & qhip (updtpp) & updmujp & \\
\hline 1.1 & 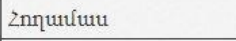 & Tur 2 unumutulur & ก२ & $10,000,000.00$ & 2Z nnuu & & & ก२ \\
\hline 1.2 & 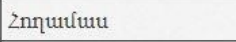 & Turzuquiulur & ก२ & $4,500,000.00$ & 22 nnuu & & & ก२ \\
\hline 1.3 & 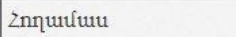 & 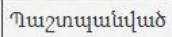 & ก२ & $1,600,000.00$ & 22 npuu & & & ก२ \\
\hline 1.4 & 2nๆuruiuu & Turznuquiu|ur & ก२ & $2,000,000.00$ & Z2 nnuu & & & ก२ \\
\hline 1.5 & 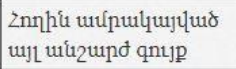 & 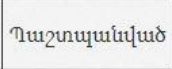 & UBก & & & $48,500,000.00$ & 22 npuur & ก२ \\
\hline 1.6 & 2nๆurutuu & 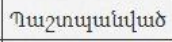 & Uвก & & & $1,029,500,000.00$ & 22 nnuuu & ก२ \\
\hline 1.7 & Znпưfuu & 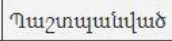 & ก२ & & & $10,000,000.00$ & 22 npuud & ก२ \\
\hline 1.8 & 2nпุuưưu & 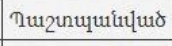 & ก२ & & & $4,500,000.00$ & 22 nnuux & ก२ \\
\hline 1.9 & Znๆ & Turzenumitulus & ก२ & & & $1,600,000.00$ & 22 npuud & ก२ \\
\hline 1.10 & 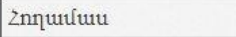 & Tuг2unumitur & กर & & & $2,000,000.00$ & 22 npuud & ก२ \\
\hline
\end{tabular}

\begin{tabular}{|c|c|c|c|c|c|c|c|c|}
\hline \multirow{3}{*}{$\begin{array}{l}\mathrm{NN} \\
\mathrm{p} / \mathrm{l}\end{array}$} & \multicolumn{8}{|c|}{ 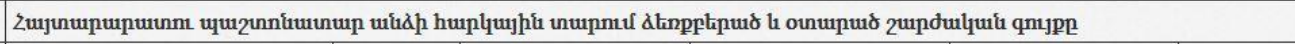 } \\
\hline & \multirow{2}{*}{ Stuuulyp } & \multirow{2}{*}{$\begin{array}{l}\text { Utiphuit, } \\
\text { Uulqup2n }\end{array}$} & \multirow{2}{*}{$\begin{array}{l}\text { Unlqu t, huplquishis } \\
\text { nupulu ulqqpis }\end{array}$} & \multicolumn{2}{|c|}{$\begin{array}{l}\text { 2tinp tptaplth } \\
\text { huplquuphi unupnud }\end{array}$} & \multicolumn{2}{|c|}{$\begin{array}{l}\text { Onupultat: } \\
\text { huplquijhis unupmud }\end{array}$} & \multirow{2}{*}{$\begin{array}{l}\text { Unluut } \\
\text { huplyuujhit } \\
\text { unupulu } \\
\text { thpenud }\end{array}$} \\
\hline & & & & $\begin{array}{l}\text { qhip } \\
\text { (updtipn) }\end{array}$ & updnıjp & $\begin{array}{l}\text { qhip } \\
\text { (updtpp) }\end{array}$ & updmujp & \\
\hline 2.1 & 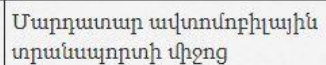 & $\begin{array}{l}\text { BMW X5 } \\
\text { M } 4.4\end{array}$ & ก२ & $64,089,000.00$ & 22 nnuuf & & & Uвก \\
\hline
\end{tabular}

Figure 2 Original version of Asset and Income declaration retrieved from the website of The Commission on Ethics of High-Ranking Officials

\footnotetext{
${ }^{6}$ Scripts are lists of commands executed by certain programs or scripting engines. They are usually text documents with instructions written using a scripting language. They are used to generate Web pages and to automate computer processes (Techopedia, n.d.).

${ }^{7}$ Machine-readable is the data that can be read through an electronic device for interpretation and manipulation by a computer (Dictionary, n.d.).
} 
After the scraping of all needed data, the next step was editing and completing the PEPs' profiles. The journalist/researcher manually went through each profile, added photos, dates of births, corrected minor errors and inputted bios/contacts.

\begin{tabular}{|c|c|c|c|c|c|c|c|c|}
\hline id 1. & nn & type & currency & startValue & acquiredValue & removedValue & endValue comment & dsd \\
\hline 770 & 3.1 & Furdutunnulu & 22 nnur & 15000 & 0 & 15000 & 0 & छ \\
\hline 771 & 3.2 & Furduturun & 22 nnuur & 6888000000 & 0 & 799212000 & 6088790000 & ब \\
\hline 772 & 3.3 & Furduturius & 22 nnuur & 12500 & 0 & 12500 & 0 & ब \\
\hline 773 & 3.4 & Fudutunnulu & 22 nnumu & 50000 & 0 & 50000 & 0 & - \\
\hline 774 & 3.5 & Furdutrum & nntumlüu nnเpLh & 10408 & 0 & 10408 & 0 & E \\
\hline 775 & 3.6 & Furduturuu & 22 nnuur & 15000 & 0 & 15000 & 0 & - \\
\hline 776 & 3.7 & Furduturuu & 22 nnuur & 50000 & 0 & 50000 & 0 & छ \\
\hline 777 & 3.8 & Furdutuluu & 22 nnuru & 25000 & 0 & 25000 & 0 & - \\
\hline 778 & 3.9 & Furdutulun & 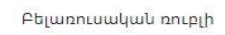 & 11060 & 2169.08 & 0 & 13229.1 & - \\
\hline 779 & 3.10 & Furduturuu & 22 nnuru & 250000 & 59792800 & 0 & 60042800 & ฮ \\
\hline 780 & 3.11 & Furduturun & 22 nnwur & 0 & 50000 & 0 & 50000 & - \\
\hline 781 & 3.12 & Furdutudur & 22 nnuru & 0 & 50000 & 0 & 50000 & च \\
\hline 782 & 3.13 & Furduturun & 22 nnumu & 0 & 25000 & 0 & 25000 & च \\
\hline 783 & 3.14 & Fuchturum & 22 nnuru & 0 & 25000 & 0 & 25000 & - \\
\hline 784 & 3.15 & Furduturuu & 22 nnwur & 0 & 799212000 & 0 & 799212000 & - \\
\hline 785 & 3.16 & Furdutunnuru & 22 nnumu & 0 & 50000 & 0 & 50000 & - \\
\hline 786 & 3.17 & Furdutunnuu & 22 nnuur & 0 & 1078000000 & 1078000000 & 0 & ] \\
\hline
\end{tabular}

Figure 3 Machine-readable version of Asset and Income declaration scraped for our database.

As for the relation map, the journalist/researcher researched several sources to determine people who have personal or business ties with Members of Parliament. The first source of information was the website of The Commission on Ethics of High-Ranking Officials; however, it contained only information about people who lived with the official. Therefore, the children of politicians who do not live with them remain undocumented. To solve this issue, the journalist/researcher used the Voter's Registry data where all people who are registered on the politician's address are visible. This allowed for everyone - not only family members but also siblings and other relatives who are registered at the same address - to be included in the database. 
Publication of the project

This professional project will be published in Hetq Online Newspaper, the only investigative journalism portal in Armenia that has been established in 2001 by the Investigative Journalists NGO. The content is in three languages: Armenian, English and Russian. In 2004, Transparency International rewarded Hetq for its outstanding contribution to the struggle against corruption. Investigative Journalists NGO is a member of several international journalism networks such as Organized Crime and Corruption Reporting Project, International Consortium of Investigative Journalists, Global Investigative Journalists Network and International Center for Journalists.

Methodology:

The professional project utilized the Data Journalism Inverted Pyramid Method proposed by Bradshaw (2013). This method suggests five steps in a sequence that need to be taken to produce a data-driven journalism project: compiling, cleaning, giving context, combining and communicating data. 


\section{The Inverted Pyramid of Data Journalism}

Paul Bradshaw, OnlineJournalism Blog.com

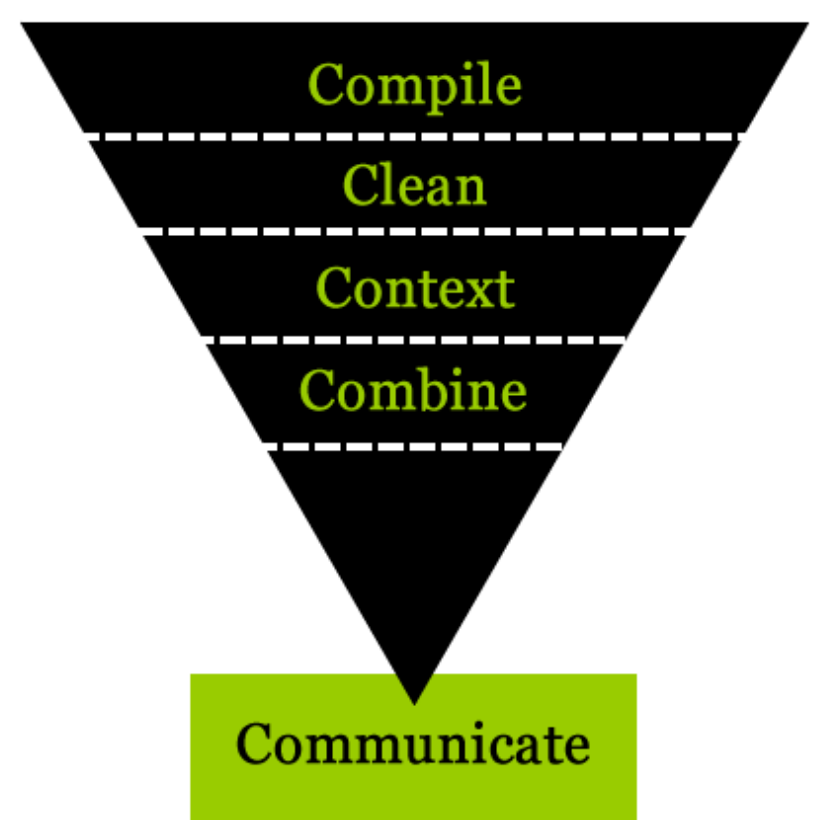

Figure 4 Inverted Pyramid developed by Paul Bradshaw
Compile: Data can be obtained by a journalist in different ways. It can be supplied by some organizations, open source databases or government websites. The journalist may also find data by using advanced searching tools, scraping from online forms and pages or pulling from open $\mathrm{APIs}^{8}$. Journalists also can collect their own data via surveys, online forms or personal observations. In this case, the Asset and Income database of Armenian PEPs has compiled data by scraping information from the asset and income declaration forms.

Clean: Cleaning data is one of the important steps when creating databases because even minor errors can lead to major mistakes while drawing conclusions. There can be human errors, such as duplicates, corrupted entries, or incorrect formatting in large datasets. The human error was eliminated in this database because the main data was scraped by machine. However, it was necessary to go over it, check the numbers and make sure that the script's logic worked properly. Some key fact had to be added manually, such as the PEPs photos, addresses, connected people, and bios.

\footnotetext{
8 Open Application Programming Interface uses a universal programming language which allows developers to fit a specific data into third-party projects (Techopedia, n.d.).
} 
Context and Combine: Journalists need to question the data itself. Each dataset is created with a specific objective, so it is crucial for a data journalism team to clearly understand the context behind data being researched, especially when it is published by the government. For example, the aim of Armenia's Commission on Ethics of HighRanking Officials was not about finding corruption or conflict of interest but to formally integrate international anti-money laundering standards.

As in traditional journalism, data journalism also requires a combination of several data sources. To accomplish this, the researcher combined several datasets from different sources to verify the trustworthiness of the information included in the database compiled for this project. Specifically, a cycle of verification plan was developed that combines several national and international data sources.

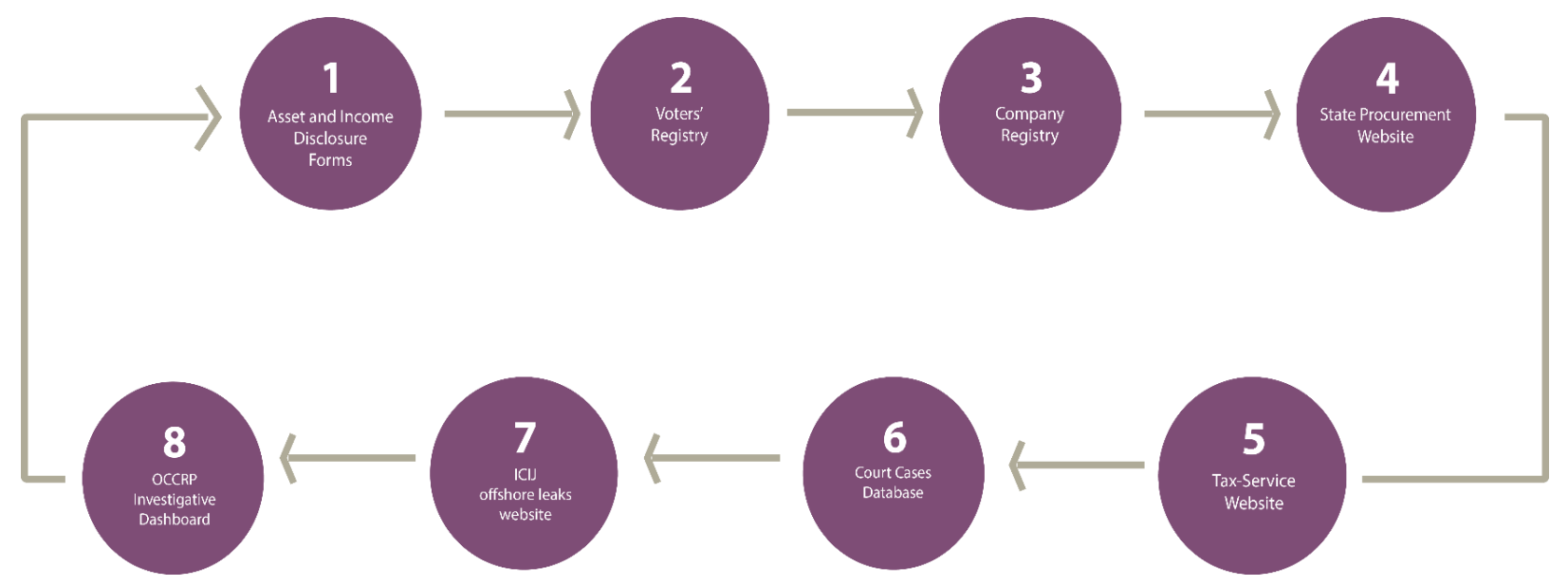

Figure 5 Cycle of verification plan will be followed while finding context in data.

1. Asset and Income Disclosure Forms: This data source was used to determine the wealth of PEPs.

2. Voters' Registry: Data was used to find the family members and relatives of the PEPs. 
3. Company Registry: This registry contains data about companies' owners, shareholders, tax codes, addresses, and corporate charters. One can search a subject's name in this database and find out all business entities that the person relates to. Analysis of this data will make it possible to reveal if the PEP has declared all the shares he owns or not ${ }^{9}$.

4. State Procurement Website: After indicating what companies PEPs own, this database was used to research if these companies took part in state procurement tenders. There were many cases during the previous government when politically exposed people's companies won tenders and supplied goods and services to the government in the result of corrupted deals. The Commission on Ethics of High-Ranking Officials researched 2181 asset disclosure forms of 489 high-ranking officials and 283 forms of their spouses to find out how many of them have business entities that supplied goods and services to the state institutions. The Commission revealed that in the last four years 91 business entities belonging to a high-ranking official or a spouse were the suppliers of state procurement (Balasanyan, Hetq.am, 2018). This image makes it primary to check the PEPs' companies' involvement in state procurements.

5. Tax Service Website: This is a useful source to find out the type of activity of a company and taxes paid by that company annually. Combination of datasets

\footnotetext{
9 To acquire data from the Companies' registry one need to pay. Each company's data costs about $\$ 6$ USD. However, it is a onetime purchase meaning that the buyer will not hold further updates about the company. The government of Armenia initiates a change in law which will make Companies' registry data available for journalists for free. This step will be implemented as soon as data is available.
} 
from the Asset Declaration Registry, Company Registry, and Tax Service website will allow disclosing tax avoidance cases if there are any.

6. Court Cases Database: there is a public database where all civil, criminal and administrative court cases are recorded. This database will be researched to find out if a PEP or his/her company were involved in any court proceedings. For example, for not paying taxes PEPs' company may have faced administrative charges.

7. International Consortium of Investigative Journalists' Database: this database contains information on business entities that are registered in offshore 10. Documents of over 785000 business entities from more than 200 countries are uploaded in this database. ICIJ collected all these files from famous leaks such as Offshore Leaks, the Paradise Papers, the Panama Papers, and the Bahamas Leaks. Some of the Armenian high-ranking officials' and their companies' names were found in this leak too. Former prime-minister Tigran Sargsyan (Baghdasaryan, Aghalaryan, \& Davtyan, Hetq, 2013) and former Chief Compulsory Enforcement Officer Mihran Poghosyan (Baghdasaryan \& Aghalaryan, Hetq, 2016) were found in Offshore Leaks and the Panama Papers accordingly. Therefore, it worth to also go through offshore data while investigating PEPs.

\footnotetext{
10 Offshore refers to a location outside of one's national boundaries, whether that location is land or waterbased. The term "offshore" may be used to describe foreign banks, corporations, investments and deposits. A company may legitimately move offshore for tax avoidance or to enjoy relaxed regulations. Offshore financial institutions can also be used for illicit purposes such as money laundering and tax evasion (Investopedia).
} 
8. Organized Crime and Corruption Reporting Project's Investigative Dashboard is a common space for investigative journalists from around the world. It combines various databases and tools in one portal to help journalists to easily find all possible information about a PEP they are interested in. It is a network of journalists that help each other to find information. For example, if a journalist from Ecuador needs data from the UK's Companies House, a colleague from the UK will help with that. Investigative Dashboard's databases can be a useful source for this project to indicate Armenian PEPs who have registered business entities abroad. 
Communicate: This is the last stage of the chosen method: communicating the findings with the public. There will be two formats of visual storytelling for this project: a website with searchable database and a tool to create stories out of the data.

The website with searchable database is ready (url: https://data.hetq.am/en). It was constructed using a minimalistic web design style to facilitate user experience. By using a search bar or filters users can find the MP's profile they are interested in.

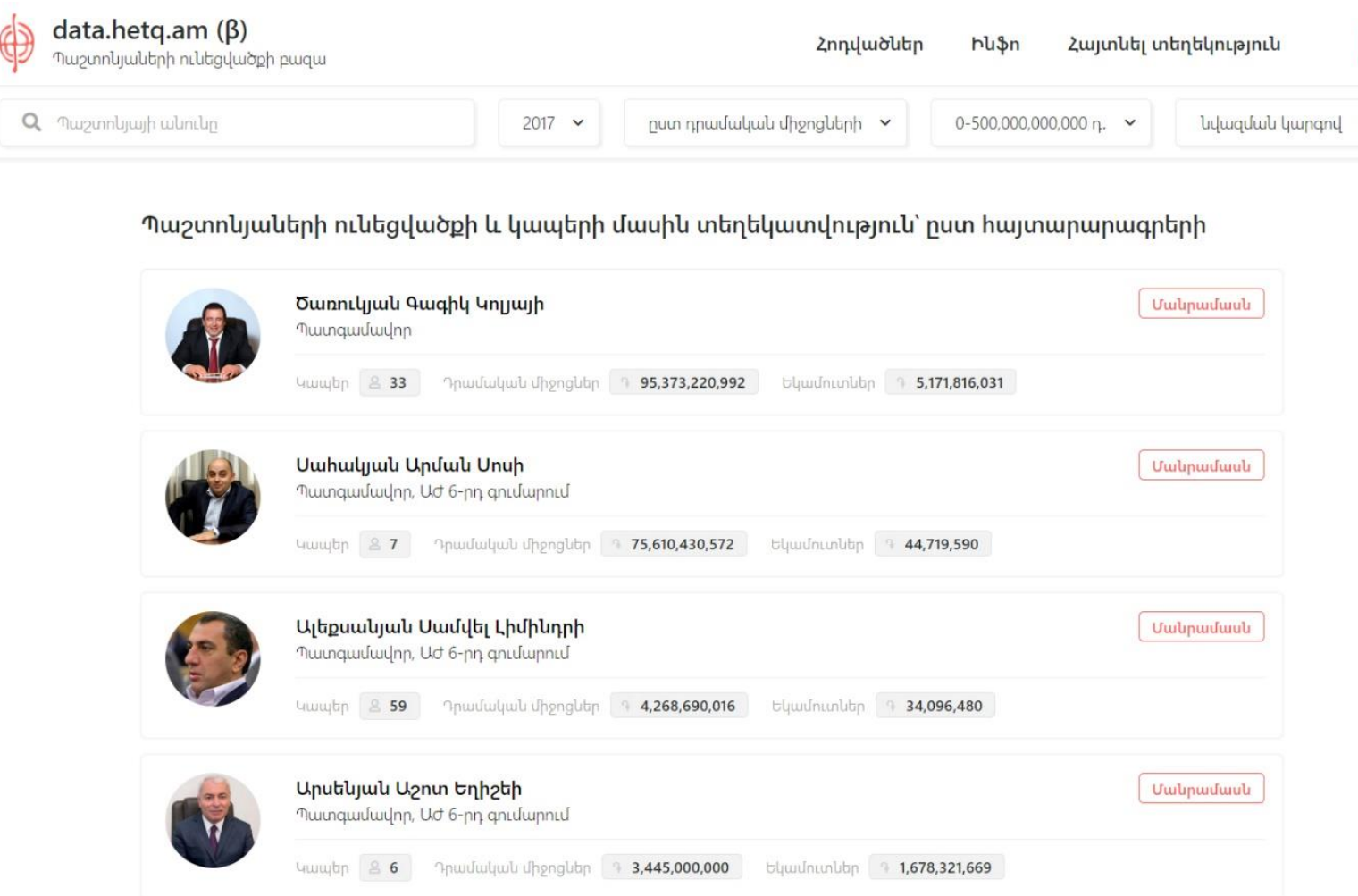

Figure 6 Screenshot of the searchable database's Home Page

At the top of the website's home page, there is a search box and classification filters. Each official has their profile at data.hetq.am, with their biography, map of affiliates, cash schedule, movable and immovable property, as well as information on securities, loans, real estate and income. To go to a specific official's profile users can write down the name of the person in the search box. 
If users are interested not only in one person but in the trends, four filters will make it possible to filter down the information by year, by income, by affiliated people count, by cash, by ascending or descending order. This enables to arrange the officials in terms of money, income, or affiliated individuals on a yearly basis.

All features in the website are reusable which means that users can copy the embed code and place it in their websites. Besides, they can download raw data by clicking on "download" button.

Discussion

Data.hetq.am contains almost 2500 profiles of PEPs from Armenia's legislative (206), executive (214) and judiciary (576) powers as well as their affiliates (1494). Every month more profiles are being updated and published in the website. According to Google Analytics, since the publication of the website (July $22^{\text {nd }}, 2019$ ) there were 10,690 pageviews with average 2.25 minutes session duration and 54.2 percent bounce rate. In average 2.71 pages were viewed during a session. 87.4 percent of website visits were new, and 12.6 percent were returning visitors. 


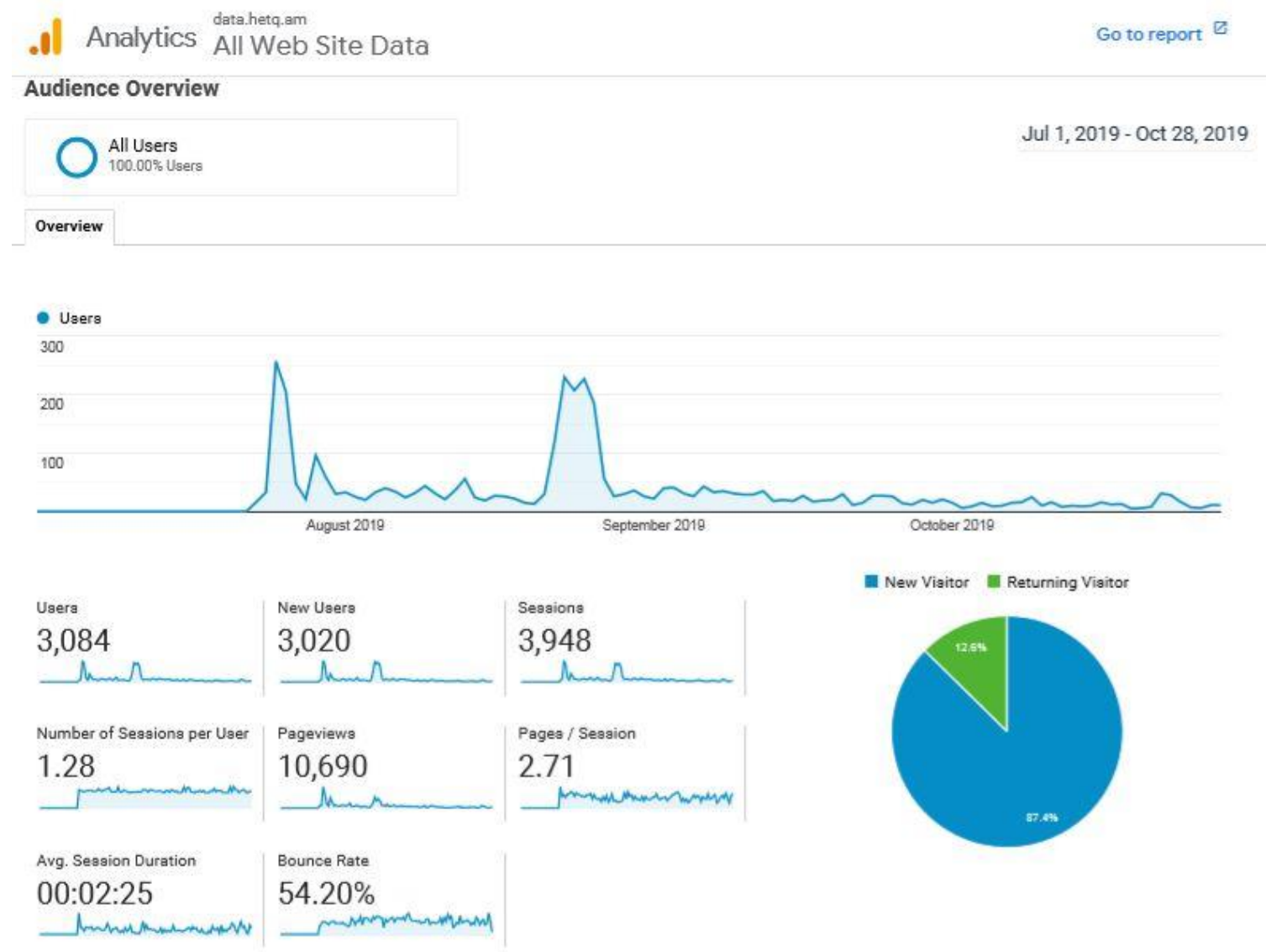

Figure 7 Google Analytics Review

The largest portion (86\%) of the visitors were from Armenia, then from the United States (3\%), and Russia (2.5\%). Overall, the website's visits came from 51 countries but most of them provided only a single click. 


\begin{tabular}{|c|c|c|}
\hline Country & Users & $\%$ Users \\
\hline 1. $\boxminus$ Armenia & 2,674 & $86.09 \%$ \\
\hline 2. 粗 United States & 92 & $2.96 \%$ \\
\hline 3. Russia & 76 & $2.45 \%$ \\
\hline 4. $\mp$ Georgia & 42 & $1.35 \%$ \\
\hline 5. $⿴$ Germany & 33 & $1.06 \%$ \\
\hline 6. $\square$ France & 24 & $0.77 \%$ \\
\hline 7. 泹 Greece & 15 & $0.48 \%$ \\
\hline 8. (not set) & 14 & $0.45 \%$ \\
\hline 9. 밀 United Kingdom & 10 & $0.32 \%$ \\
\hline 10. [«] Canada & 9 & $0.29 \%$ \\
\hline
\end{tabular}

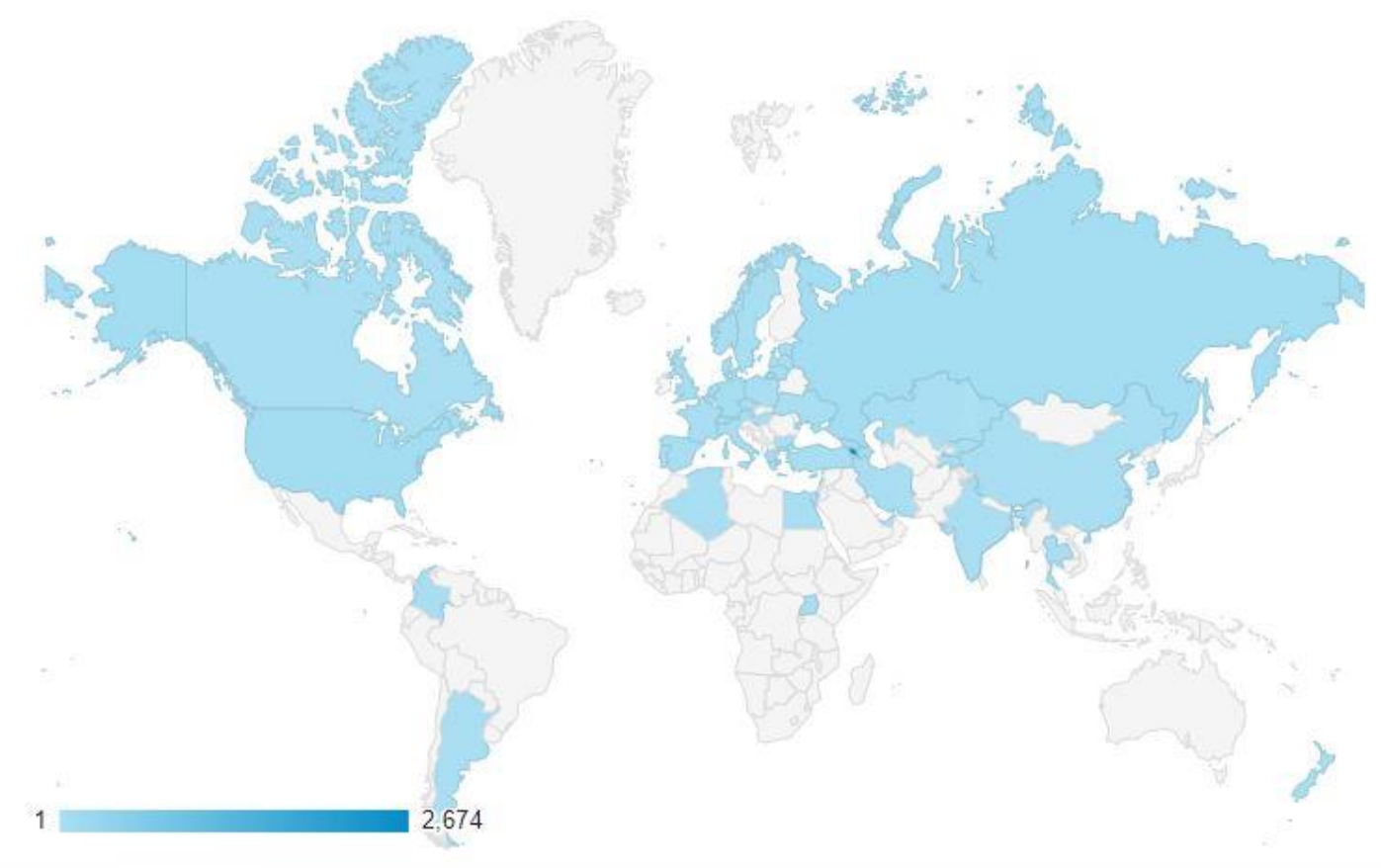

Figure 8 The Map of Visits from Google Analytics

\section{Feedback}

In addition to the database, the website has an articles section where stories about PEPs' suspicious assets are published. Data.hetq.am has received feedback and clarifications from the officials about whom the articles were published. For example, in 
an article about Bagrat Adamyan, the Deputy Head of General Department of Special Investigation Service and Election Crimes Investigation Department, it was described that he bought an apartment worth 50,000 USD when his declared funds did not exceed 10,000 USD. After the publication of the article Bagrat Adamyan contacted data.hetq.am and clarified that there was a mistake in the asset and income declaration form, and he purchased the apartment on a mortgage loan.

Data.hetq.am has received feedback from journalistic community as well. On September 27, 2019, during the local "Tvapatum (Digistory) - Stories About Change 2019" awards ceremony Honorable Mention went to data.hetq.am for covering the assets of Armenian government officials and persons linked to them.

Limitations

Facebook Graph Search ${ }^{11}$ was a great tool helping the team to quickly and accurately indicate PEPs' affiliated people. However, in June 2019 Graph Search was withdrawn by Facebook. After that twice as much time is needed to get the same findings because most of the operations previously done by the algorithm are now being done manually.

Another limitation was the incompleteness of Asset and Income Declaration Forms that prevented the integration of a statistical formula calculating the transparency rate of PEPs' assets. It was planned to develop a formula to count the transparency rate of officials based on their asset and income declarations. The formula could work if

\footnotetext{
${ }^{11}$ Facebook Graph Search was a semantic search engine that helped to map relationships among Facebook users. Graph Search algorithm could find information from within a user's network of friends. Since December 2014, Facebook made it less visible publicly, and in June 2019 the Graph Search was removed.
} 
complete, accurate and enough amount of data was inserted. Unfortunately, some of the public officials failed to submit complete asset declarations as a result of which the team decided not to calculate PEPs' transparency rate.

Updates and upcoming features

Two people constantly update the database to make sure that information provided in the website is up to date. Besides that, every month on average 30 new profiles of PEPs are being added to the database.

A new tool for creating multimedia stories out of raw data is in the processing step: currently the team is working on creating the mockup and template design. That will allow journalists to not only find, download and analyze data but also to visualize and share their findings.

The storytelling template will be an open source tool with the possibility of code export which means that journalists from other newsrooms can download and adjust the code of their story for their website's hosting.

The combination of database and storytelling tool will become an alternative public resource for journalists and citizens of Armenia to follow the money and keep politically exposed people accountable.

Conclusion

The World Bank Group has initiated the Asset Disclosure Standard among 176 client countries, but implementation of it has been left to the discretion of the given country. Some countries have not implemented the Standard at all, others have developed public or partially public financial disclosure systems. Armenia was one of 
those countries with semi-public asset and income declarations' website full of disorganized tables printed on "pdf" files. Taxpayers were deprived of the opportunity to easily access information about officials' wealth.

This data-driven professional project made Armenia's asset disclosure database more accessible to the public by converting non-machine-readable files into an organized, searchable, interactive and visualized database. Users can easily search, access, analyze, visualize, download and reuse data about public officials' and their affiliates' assets and income.

Following the concept of social responsibility theory, this project aims to increase citizens' awareness to hold their government accountable. In comparison to state disclosure system, data.hetq.am not only organizes but also analyzes PEPs' financial disclosure forms. Twenty articles have already been published at data.hetq.am about PEPs' suspicious money and donations. In other words, data.hetq.am gives life to thousands of documents that were left untouched in a state-owned website since 2012.

In today's global world, journalism also goes global. To track politicians' crossborder money, investigative reporters often have to conduct cross-border research. In that respect, data.hetq.am can serve as a tool for international journalists to find information on Armenian officials and their affiliates. That is why creation of an English version of the database has been very important during the implementation of the project.

Every database is alive if data is being constantly updated in it. More and more PEPs' profiles are being added to this database every month. Besides, a new component is planned to be developed that will include information about the companies where PEPs' 
are shareholders. This is a continuous project that has adopted Paul Bradshaw's inverted pyramid method to permanently compile, clean, combine and give context to datasets uncovering PEPs' assets. 
Bibliography

Aitamurto T., S. E. (2011). Trends in Data Journalism.

Akhavan-Majid, R. (1991). American Mass Media and the Myth of Libertarianism:

Toward an "Elite Power Group" Theory. Mass Communication Faculty Publications, 10.

Amendments to the Constitution of the Republic of Armenia. (2015, 06 12). National Assembly of the Republic of Armenia. Retrieved from parliament.am: http://www.parliament.am/parliament.php?id=constitution\&lang=eng

Armstat. (2015). Armstat. Retrieved from Armstat.am: http://www.armstat.am/en/?nid=12\&id=08001

Baghdasaryan, E., \& Aghalaryan, K. (2016, April 04). Hetq. Retrieved from hetq.am: https://hetq.am/en/article/66918

Baghdasaryan, E., \& Aghalaryan, K. (2018, 04 09). Hetq. Retrieved from hetq.am: https://hetq.am/en/article/87243

Baghdasaryan, E., Aghalaryan, K., \& Davtyan, A. (2013, June 27). Hetq. Retrieved from hetq.am: https://hetq.am/en/article/27709

Balasanyan, G. (2014, October 20). Hetq Online. Retrieved from Hetq.am: http://hetq.am/eng/news/56953/all-in-the-family-armenian-prime-ministersboomingt

Beaudet, M. W.-S. (2016). The State Financial Disclosure Project. Retrieved from The State Financial Disclosure Project: https://web.northeastern.edu/disclosureproject/

Blanchard, M. A. (1977). In M. A. Blanchard, The Hutchins Commission, The Press and the Responsibility Concept. Association for Education in Journalism.

Bradshaw, P. (2013). Online Journalism Blog. Retrieved from onlinejournalismblog.com: https://onlinejournalismblog.com/2011/07/07/the-inverted-pyramid-of-datajournalism/

Cabra , M., \& Kissane, E. (2016, April 11). Open News. Retrieved from source.opennews.org: https://source.opennews.org/articles/people-and-techbehind-panama-papers/

Coddington, M. (2015). Clarifying Journalism's Quantitative Turn, Digital Journalism. 
Constantaras, E. (2016). Data Journalism Manual. Retrieved from http://www.odecanet.org/data-journalism-manual/

Corruption Perception Index. (2014). Retrieved from Transparency International: https://www.transparency.org/cpi2014/results

Corruption Perception Index. (2016). Retrieved from Transparency International: https://www.transparency.org/new/feature/corruption_perception_index_2016

Decision of the Prime Minister N847-A. (2015, September 18). gov.am. Retrieved from Government of Armenia: http://www.gov.am/u_files/file/xorhurdner/korupcia/anhatakan\%20kazm.pdf

Declarations Registry of Armenia. (2017). The Commission on Ethics of High-Ranking Officials. Retrieved from ethics.am: http://www.ethics.am/hy/declarationsregistry/group_id=353page $=5 /$

FATF. (2012). International Standards on Combating Money Laundering and the Financing of Terrorism and Proliferation. Paris, France: FATF. Retrieved from http://www.fatf-gafi.org/publications/fatfrecommendations/documents/fatfrecommendations.html

Garside, J., Watt, H., \& Pegg, D. (2016, April 3). The Guardian. Retrieved from theguardian.com: https://www.theguardian.com/news/2016/apr/03/the-panamapapers-how-the-worlds-rich-and-famous-hide-their-money-offshore

GIJN. (2018, March 13). gijn.org. Retrieved from GIJN: https://gijn.org/asset-disclosure/

Gray, J., Bounegru, L., \& Chambers, L. (2012). The Data Journalism Handbook. Sebastopol: O'Reilly Media Inc.

Greenberg, T. S., \& Gray, L. (2010). Politically Exposed Persons: Preventive Measures for the Banking Sector. Washington D.C.: The World Bank. Retrieved from https://star.worldbank.org/sites/star/files/Politically\%20Exposed\%20Persons_0.p df

Grigoryan, M. (2015, August 12). The Guardian. Retrieved from theguardian.com: https://www.theguardian.com/world/2015/aug/12/armenia-corruption-lavishspending

Hattenstone, S. (2012, May 11). The Guardian. Retrieved from theguardian.com: https://www.theguardian.com/politics/2012/may/11/mps-expenses-scandal-whatnext 
Hewett, J. (2017). Collaborative learning: from CAR to data journalism and Hacks/Hackers. Bury St Edmunds: Abramis, 5-22.

Hutchins, R. M., \& Chafee, Z. J. (1947). A Free and Responsible Press. Chicago.

Jenkins, H. (2006). Fans, Bloggers and Gamers: Exploring Participatory Culture. New York: New York University Press.

Kroll, L. (2016, April 5). Forbes.com. Retrieved from Forbes: https://www.forbes.com/sites/luisakroll/2016/04/05/panama-papers-fallouticelands-pm-resigns-ukraines-under-pressure-russian-billionaireresponds/\#74bc70314cc8

López, F. T. (2017, 07 11). GIJN. Retrieved from gijn.org: https://gijn.org/2017/07/11/how-to-create-a-data-journalism-team/

López, F. T. (2017, July 11). Global Investigative Journalism Network. Retrieved from gijn.org: https://gijn.org/2017/07/11/how-to-create-a-data-journalism-team/

McIntyre, J. S. (1987). Repositioning a Landmark: The Hutchins Commission and Freedom of the Press. In J. S. Mclntyre, Repositioning a Landmark: The Hutchins Commission and Freedom of the Press. EBSCO.

Meyer, P. (1991). The New Precision Journalism.

Obermaier, F., Obermayer, B., Wormer, V., \& Jaschensky, W. (2017, September 3). Süddeutsche Zeitung. Retrieved from http://panamapapers.sueddeutsche.de: http://panamapapers.sueddeutsche.de/articles/56febff0a1bb8d3c3495adf4/

Open Data Barometer. (2015). Retrieved from Open Data Barometer: http://opendatabarometer.org/doc/3rdEdition/ODB-3rdEdition-GlobalReport.pdf

Open Government. (2017). Data.gov. Retrieved from Data.gov: https://www.data.gov/open-gov/

Rogers, S. (2009, June 18). The Guardian. Retrieved from theguardian.com: https://www.theguardian.com/news/datablog/2009/jun/18/mps-expenseshouseofcommons

Rogers, S. (2012, September 20). The Guardian. Retrieved from theguardian.com: https://www.theguardian.com/news/datablog/2012/sep/20/open-data-journalism

Rossi, I., Pop, L., Clementucci, F., \& Sawaqed, L. (2012). Using Asset Disclosure for Identifying Politically Exposed Persons. Washington D.C.: The World Bank. Retrieved from 
http://siteresources.worldbank.org/FINANCIALSECTOR/Resources/Using_AD_fo r_PEP_identification.pdf

Samvel Aleksanyan's Declaration. (2017). Retrieved from The Commission on Ethics of High Ranking Officials: http://www.ethics.am/hy/declarationsregistry/user_id=365/

Stepanets, S. \&. (2011, January). Unchartered Warers: The State of Open Data in Europe. Retrieved from https://joinup.ec.europa.eu/sites/default/files/files_epractice/sites/Unchartered\%2 OWaters\%20-\%20The\%20State\%20of\%20Open\%20Data\%20in\%20Europe.pdf

Transparency International. (2013, January 17). Holding Politicians to Account. Retrieved from transparency.org:

https://www.transparency.org/news/feature/holding_politicians_to_account_asset _declarations

Uzuegbunam, C. (2015). THE SOCIAL RESPONSIBILITY THEORY OF THE PRESS: A CONTEMPORARY REVIEW. ResearchGate.

World Bank Group. (2017, September 26). Combating Corruption. Retrieved from worldbank.org: http://www.worldbank.org/en/topic/governance/brief/anticorruption

World Bank Press Release. (2012, November 8). Worldbank. Retrieved from Worldbank.org: http://www.worldbank.org/en/news/pressrelease/2012/11/08/only-fourty-three-percent-countries-disclose-public-officialsfinancial-assets-says-world-bank

worldbank.org. (2012). Retrieved August 21, 2017 